\title{
Pemanfaatan UKS dalam Pencegahan Anemia pada Anak Sekolah Dasar di Daerah Endemik Malaria
}

\author{
Khairunnisa ${ }^{1}$, Rostika Flora ${ }^{2}$, Haerawati Idris ${ }^{3}$, Nurlaili $^{4}$, Ikhsan $^{5}$ \\ Universitas Sriwijaya ${ }^{1}$ \\ Fakultas Kesehatan Masyarakat Universitas Sriwijaya ${ }^{2,3}$ \\ Prodi Keperawatan Fakultas MIPA Universitas Bengkulu ${ }^{4,5}$ \\ aniskhairunnisa20@yahoo.co.id ${ }^{1}$
}

\begin{abstract}
Diajukan 16 Juli 2019 Diperbaiki 30 Januari 2020 Diterima 24 Februari 2020
ABSTRAK

Latar Belakang: Usia yang rawan terkena penyakit terjadi pada anak-anak dan remaja. Pemerintah berusaha menciptakan lingkungan sehat, menyebarkan pengetahuan kesehatan dan menyediakan fasilitas layanan kesehatan melalui UKS. Di daerah endemik malaria, anak sekolah dasar rentan mengalami anemia. Kondisi lingkungan endemik dan kurangnya asupan nutrisi meningkatkan terjadinya anemia. Di Kabupaten Seluma tahun 2019 didapatkan 21,08\% dari 137 anak sekolah dasar menderita anemia.

Tujuan: Melakukan analisis pemanfaatan UKS dalam pencegahan anemia pada anak sekolah dasar di daerah endemik malaria.

Metode: Penelitian kualitatif, pemilihan informan secara purposive. Pengambilan data dengan wawancara mendalam kepada 10 informan, observasi dan telaah dokumen. Triangulasi sumber,

mereduksi, menyajikan, menarik kesimpulan dan memverifikasi.

Hasil: Pemanfaatan UKS melalui pendidikan kesehatan dilakukan dengan memberikan informasi kesehatan oleh guru dan petugas kesehatan. Pemanfaatan UKS dalam pelayanan kesehatan untuk mencegah anemia dengan memantau status gizi anak sekolah dasar dan pemeriksaan konjungtiva, namun belum maksimal karena hanya dilakukan sekali setahun dan belum ada pengecekan kadar hemoglobin. Sarana dan prasarana program UKS untuk pemantauan anemia belum lengkap dan pemanfaatannya terbatas.

Kesimpulan: Pemanfaatan UKS dalam pencegahan anemia belum optimal. Sekolah diharapkan meningkatkan pemahaman guru tentang pencegahan anemia melalui kerjasama dengan Puskesmas.
\end{abstract} metode dan data. Analisis data dengan cara

Kata Kunci: UKS; Sekolah Dasar; Guru; Puskesmas

\section{ABSTRACT}

Background: The susceptible age to the disease occurs in childhood and adolescence. The government creates a healthy environment, disseminate health knowledge and provide health care facilities through the UKS. In malariaendemic areas, primary school children are anemia susceptible. Environmental conditions and malnutrition increase anemia. In Seluma District in 2019 it was $21.08 \%$ anemia of 137 primary school children.

Objective: To analyze the UKS utilization in preventing primary school children anemia in malaria-endemic areas. Methods: Qualitative research, purposive informants selection. Data retrieval by in-depth interviews with 10 informants, observation, and documents study. Data analysis was done by reducing, presenting, drawing conclusions and verifying.

Results: UKS Utilization was done by giving health information by teachers and health workers, monitoring the student nutritional status and examining the conjunctiva but has not run optimally because it was done once a year, there is no checking hemoglobin. The UKS program facilities and infrastructure for anemia monitoring are incomplete and their use is also limited.

Conclusion: UKS Utilization in anemia prevention is not optimal. Schools are expected to increase teacher knowledge of anemia through collaboration with the Community Health Center.

Keywords: School Health Program; primary school; teacher; Community Health Center 


\section{PENDAHULUAN}

Perkembangan sumber daya manusia dipengaruhi oleh dua aspek yang sangat penting, yaitu pendidikan dan kesehatan. Usia yang mudah terkena risiko penyakit dalam masa tumbuh kembang terjadi diusia kanakkanak dan remaja. WHO mengikutsertakan tenaga pengajar, anak sekolah, petugas kesehatan dan pemberi layanan kesehatan serta orang tua dalam upaya untuk menciptakan lingkungan sehat, menyebarkan pengetahuan tentang kesehatan dan menyediakan fasilitas layanan kesehatan yang baik melalui suatu program Health Promoting School (WHO dan UNESCO, 2018). Pelaksanaan program tersebut dikenal dengan Usaha Kesehatan Sekolah (UKS) di Indonesia.

UKS adalah suatu upaya peningkatan kesehatan anak sekolah yang dilakukan pemerintah sehingga anak berkualitas dan berprestasi. Bentuk usaha yang dilakukan antara lain dengan kegiatan promosi kesehatan yang bertujuan untuk memberikan edukasi kesehatan. Upaya peningkatan pengetahuan hidup sehat kepada mereka dilakukan melalui kegiatan intrakulikuler, ekstrakulikuler dan kegiatan lainnya dalam rangka pembinaan dan pemeliharaan kesehatan sejak dini (Kemendikbud, 2014). UKS sebagai bentuk strategi peningkatan layanan kesehatan primer di sekolah perlu dilakukan supaya kesehatan anak sekolah bisa ditingkatkan secara optimal (Juniarti et al., 2017).

Permasalahan kesehatan yang dijumpai pada anak usia sekolah sangat kompleks dan beragam. Pada usia ini anak cenderung rawan terserang penyakit, baik yang dari lingkungan sekitar ataupun dirinya sendiri. Faktor perilaku yang berisiko pada anak usia sekolah antara lain tidak mencuci tangan dengan benar, sedikit konsumsi buah-buahan dan sayur serta aktifitas fisik yang kurang. Anemia merupakan permasalahan kesehatan yang berkaitan dengan perilaku tidak sehat anak usia sekolah (Salama dan Labib, 2016).

Anemia adalah kondisi dimana sel darah merah sebagai pembawa oksigen tidak cukup untuk memenuhi kebutuhan fisiologis tubuh. Apabila konsentrasi hemoglobin dalam darah seseorang lebih rendah dari batasan yang sudah ditentukan maka orang tersebut dikatakan menderita anemia. Batasan hemoglobin dalam darah untuk anak berusia 5 sampai 11 tahun yaitu 11,5 g/dl (WHO, 2011). WHO melaporkan bahwa terdapat permasalahan gizi secara global, salah satunya anemia. Penderita anemia di seluruh dunia mencapai 1,622 miliar penduduk. Dari jumlah angka tersebut 25\% merupakan anak-anak sekolah. Di Indonesia angka kejadian anemia pada anak berusia 5 sampai 14 tahun sebanyak 26,4\% (Badan Penelitian dan Pengembangan Kesehatan, 2013).

Anemia yang terjadi di usia sekolah dasar berdampak terhadap gangguan pertumbuhan fisik, penurunan daya tahan tubuh, kecerdasan menurun, prestasi dan konsentrasi belajar berkurang dan selalu tampak lesu, pucat serta tidak bersemangat (Devi, 2012). Indeks massa tubuh rendah, imunitas menurun, sering sakit, mudah terinfeksi dan perubahan psikomotorik yang lambat merupakan manifestasi dari anemia anak. Hal ini dikarenakan pentingnya peranan zat besi dalam upaya mempertahankan daya tahan tubuh dengan proses biokimia dan cellular (Soliman et al., 2014).

Kabupaten Seluma berada di Provinsi Bengkulu dan berdasarkan Perpres No. 131 Tahun 2015 termasuk dalam wilayah yang tertinggal dimana kriteria penetapannya dilihat dari ekonomi masyarakatnya. Minimnya penghasilan masyarakat berpengaruh terhadap kemampuan pemenuhan kebutuhan nutrisi yang baik bagi keluarganya, terutama untuk anak dalam masa usia sekolah karena akan berpengaruh terhadap gizi anak. Anak usia sekolah juga termasuk golongan yang rentan terhadap malaria. Faktor-faktor tersebut dapat menjadi penyebab terjadinya anemia anak di usia sekolah sehingga mengganggu kegiatan proses belajar pada anak sekolah. Oleh sebab itu untuk memantau kerjadian tersebut maka sangat 
diperlukankan keberadaan UKS.

Kegiatan UKS sudah dilaksanakan di sekolah dasar Kabupaten Seluma. Beberapa sekolah dasar dengan pelaksanaan UKS aktif pernah diikutsertakan dalam lomba sekolah sehat. Namun, penerapan UKS masih kurang optimal, contohnya ada yang belum mempunyai ruangan UKS dan sarana prasarana UKS masih belum sesuai standar. Berdasarkan hasil studi pendahuluan didapatkan bahwa di Kabupaten Seluma pada tahun 2019 anak SD yang mengalami anemia sebesar 21,08\% dari 137 orang yang diperiksa.

Dari uraian di atas, penulis tertarik melakukan penelitian dengan judul "Pemanfaatan UKS Dalam Memantau Kejadian Anemia pada Anak Usia Sekolah di Daerah Endemik Malaria".

\section{METODE}

Jenis penelitian ini adalah penelitian kualitatif. Pengumpulan data dilakukan dengan wawancara mendalam (in-dept interview), telaah dokumen dan observasi pada siswa dan lingkungan sekolah. Pemberi informasi di penelitian ini yaitu guru penanggung jawab UKS, petugas dari Puskesmas dan anak SD. Informan diambil dari 5 SDN di 5 Kecamatan Kabupaten Seluma. Informan keseluruhan penelitian ini terdiri 5 orang guru yang bertanggung jawab terhadap UKS dari SD tersebut (key informan), 5 petugas puskesmas yang melakukan pembinaan UKS pada 5 SD tersebut serta 20 anak SD yang berasal dari SD tersebut. Teknik analisis data kualitatif dalam penelitian dengan cara mereduksi, menyajikan, penarikan kesimpulan dan memverifikasi data yang ada. Peneliti melakukan metode triangulasi (gabungan), yaitu triangulasi untuk melakukan pengujian validitas data kualitatif.

\section{HASIL DAN PEMBAHASAN}

\section{A. Pemanfaatan UKS Melalui Pendidikan Kesehatan}

Dalam upaya peningkatan kesehatan siswa di sekolah, UKS berperan memberikan pendidikan tentang kesehatan untuk siswa sekolah. Pada Kabupaten Seluma pendidikan kesehatan untuk memantau kejadian anemia terhadap siswa di sekolah melalui peran UKS belum diajarkan secara khusus mengenai anemia. Berikut kutipan wawancara mendalam dari informan guru UKS:

“..kalau masalah anemia belum Bu karena kami tidak terlalu faham dan kita gak punya bukunya, kadang orang Puskesmas ke sini untuk beri penyuluhan tapi kalo anemia belum ada secara khusus. Kami menyampaikan tentang pentingnya makan pagi dan manfaatnya sebelum pergi ke sekolah, mengajarkan tentang makanan-makanan sehat, bergizi, olahraga teratur supaya anak-anak tidak mudah sakit. Biasa disampaikan dalam ruangan kelas bisa juga di luar kelas. Pada saat jam pelajaran sekolah, bisa juga pada saat upacara.." (BB)

Pendidikan kesehatan untuk anemia belum diberikan secara khusus di sekolah karena belum ada panduan khusus anemia yang disediakan sehingga guru belum terlalu mengerti tentang anemia. Pemanfaatan UKS melalui pendidikan kesehatan yang sudah diajarkan guru kepada siswa di SD, berdasarkan hasil wawancara mendalam antara lain diajarkan tentang makan bergizi, pentingnya sarapan pagi, olahraga secara teratur, dan kebersihan diri dapat membantu mencegah terjadinya anemia.

Peran guru melalui UKS ini sebagai pemberi informasi dan mengedukasi siswa di sekolah dengan pendidikan kesehatan, sehingga siswa akan terbiasa untuk menjaga kesehatan agar dapat terhindar dari anemia melalui konsumsi makanan bergizi, kebersihan diri dan olahraga. Selain peran guru, ada juga peran petugas Puskesmas dalam pelaksanaan kegiatan UKS melalui pendidikan kesehatan sekolah. Petugas Puskesmas berperan dalam memberikan penyuluhan kepada siswa ketika kegiatan UKS ke sekolah.

Pemberian pendidikan kesehatan kepada siswa juga bertujuan untuk meningkatkan kemampuan siswa agar dapat berperan aktif dalam memberikan pelayanan kesehatan. 
Upaya meningkatkan kemampuan siswa untuk berperan aktif melalui kegiatan UKS ini yang dilakukan adalah melatih kader kesehatan di sekolah yang biasa disebut dokter kecil. Ketersediaan dokter kecil pada sekolah dasar Kabupaten Seluma sudah ada 2 - 12 orang, namun jumlah tersebut belum mencukupi untuk melaksanakan peran. Pembinaan dokter kecil diberikan bagi siswa terpilih oleh petugas Puskesmas untuk nantinya membantu guru dalam kegiatan UKS. Namun pembinaaan dokter kecil untuk mencegah anemia belum dilakukan.

\section{B. Pemanfaatan UKS Melalui Pelayanan Kesehatan}

Berdasarkan wawancara mendalam, peran UKS sebagai pemantau kejadian anemia di sekolah dilakukan dengan memberikan layanan kesehatan pada siswa. Salah satu upaya pelayanan kesehatan bagi siswa di sekolah dengan melakukan penjaringan kesehatan dan pemeriksaan kesehatan pada siswa secara berkala. Penjaringan kesehatan siswa di sekolah dilakukan satu kali dalam setahun yang pelaksanaannya biasanya di awal tahun ajaran baru. Siswa dilakukan pengukuran tinggi badan dan penimbangan berat badan untuk mengetahui status dari gizinya. Kegiatan melibatkan peran guru dan peran petugas kesehatan dari Puskesmas yang diadakan di sekolah. Petugas dari Puskesmas datang ke sekolah untuk melakukan penjaringan dan pemeriksaan kesehatan siswa sebagai upaya mencegah anemia melalui peran UKS, namum belum melakukan pemeriksaan kadar hemoglobin siswa.

Penentuan siswa anemia atau tidak hanya dilakukan melalui pemeriksaan konjungtiva siswa saja. Hasil pemeriksaan kesehatan siswa hanya dicatat dalam laporan kegiatan Puskesmas saja. Sementara petugas Puskesmas belum memberikan laporan hasil pemeriksaan kesehatan pada guru. Begitu juga dengan siswa, belum diberikan laporan kesehatan berupabuku rapor kesehatan.

Hasil telaah dokumen yang dilakukan peneliti, di sekolah belum ada laporan kegiatan UKS dalam pemberian pelayanan kesehatan yang dilakukan melalui penjaringan dan pemeriksaan kesehatan berkala pada siswa. Dalam hal ini, peneliti mendapatkan laporan kegiatan UKS dalam pemberian pelayanan kesehatan penjaringan dan pemeriksaan kesehatan berkala siswa sebagai upaya memantau kejadian anemia melalui laporanlaporan kegiatan UKS yang ada di Puskesmas. Dari Puskesmas, peneliti juga menemukan dokumentasi penjaringan dan pemeriksaan kesehatan berkala pada siswa di sekolah tersebut.

Hasil observasi peneliti hanya mendapatkan buku rapor kesehatan pada satu sekolah saja, namun buku rapor kesehatan tersebut tidak mencatat hasil dari pemeriksaan kesehatan siswa yang dilakukan di sekolah. Peneliti juga mendapatkan bahwa buku rapor kesehatan siswa belum mencukupi sesuai jumlah siswa yang ada, sehingga buku rapor kesehatan tersebut hanya disimpan dalam lemari di ruang guru.

\section{Pemanfaatan Sarana dan Prasarana Penunjang UKS}

Keterlaksanaan program UKS secara optimal dapat membantu dalam pendidikan dan pelayanan kesehatan di sekolah. Keberhasilan pelaksanaan program UKS di sekolah harus diberikan dukungan dengan tersedianya sarana dan prasarana yang menunjang UKS. Prasarana utama dari program UKS di sekolah adalah adanya ruang UKS di sekolah.

Hasil wawancara mendalam menunjukkan masih terdapat sekolah yang belum mempunyai ruang UKS. Keterbatasan ruangan yang ada di sekolah sehingga sekolah belum bisa menyediakan ruangan khusus UKS. Sekolah yang sudah memiliki ruang UKS tetapi dalam pemanfaatan hanya sebatas digunakan ketika ada anak sakit sedangkan untuk sekolah yang belum memiliki ruang UKS hanya menggunakan ruang guru bila ada anak sakit. Selain itu, sarana program UKS yang dapat 
menunjang dalam memberi informasi pendidikan kesehatan pada siswa sekolah adalah media promosi kesehatan. Media ini digunakan untuk memberi pesan-pesan kesehatan dengan tujuan agar membiasakan siswa hidup sehat sehingga terhindar dari penyakit dan anemia.

Dari hasil observasi didapatkan bahwa dari sekolah-sekolah tersebut hanya ada dua sekolah yang memiliki ruangan UKS. Alat-alat UKS yang tersedia yaitu alat pengukur tinggi badan, timbangan, termometer dan contoh model organ tubuh hanya ada satu sekolah yang memilikinya. Hasil penelitian kegiatan UKS di sekolah memperlihatkan bahwa sekolah menyediakan foto-foto contoh cara cuci tangan, menjaga kebersihan diri dan makanan bergizi sebagai media promosi kesehatan. Berdasarkan triangulasi dengan petugas Puskesmas bahwa petugas Puskesmas membawa alat promosi kesehatan berupa poster saat melakukan penyuluhan ke sekolah.

\section{PEMBAHASAN}

\section{A. Pemanfaatan UKS Melalui Pendidikan Kesehatan}

Pemberian pengetahuan mengenai kesehatan pribadi bagi anak sekolah agar mereka bisa tumbuh sehat secara fisik, mental dan sosial yang diajarkan disaat jam pelajaran maupun kegiatan ekstra kurikuler merupakan wujud pendidikan kesehatan (Kemendikbud, 2014). Peningkatan pengetahuan anak sekolah dan masyarakat lingkungan sekolah dilakukan melalui pemberian pengetahuan kesehatan yang termasuk dalam kurikulum pelajaran di sekolah, dan hal ini dapat membantu meningkatkan kesehatan anak. Kualitas penyampaian materi pendidikan kesehatan yang baik oleh guru yang telah terlatih dan kompeten akan berdampak positif terhadap kesehatan (Kusmintardjo dan Gunawan, 2017).

Berdasarkan hasil penelitian, diketahui bahwa pemanfaatan UKS dalam pencegahan anemia bagi siswa di sekolah dengan pendidikan kesehatan belum dilakukan secara khusus untuk anemia. Pada negara berkembang, anemia adalah salah satu permasalahan kesehatan yang paling luas dan lebih berisiko terhadap siswa. Anemia yang terjadi saat anak usia sekolah menyebabkan daya tahan tubuh menurun, semakin rentan terhadap infeksi, buruknya perkembangan kognitif, terganggunya perkembangan fisik, buruknya kinerja sekolah hingga menurunnya kapasitas kerja dan gangguan perkembangan sosial serta ekonomi negara. Prevalensi anemia diusia sekolah diperkirakan mencapai 9\% di beberapa negara industri maju. Namun, anakanak usia sekolah kurang mendapat perhatian dibandingkan dengan anak-anak prasekolah dan wanita usia subur (Soliman et al., 2014).

Anemia dapat dicegah dengan melakukan pemberian pendidikan kesehatan untuk memperbaiki gizi siswa, seperti tentang makanan bergizi ataupun sarapan pagi. Gizi seimbang dan kebiasan pola konsumsi makanan sehat dapat mengoptimalkan tumbuh kembang siswa. Pemenuhan asupan gizi yang baik akan dapat menghindari siswa dari berbagai penyakit dan anemia(Ruel, 2008).

Guru memiliki peran untuk mengajarkan siswa tentang makanan bergizi, bisa memberikan informasi secara jelas makanan yang sebaiknya dikonsumsi siswa untuk mencegah anemia, baik itu yang bersumber dari protein nabati ataupun hewani. Guru juga dapat menjelaskan asupan yang dapat memperlambat proses penyerapan zat besi bagi tubuh, sehingga pendidikan kesehatan tentang gizi yang diberikan oleh guru menjadi baik dalam penyampaiannya.

Begitu pula tentang penyampaian pentingnya sarapan, guru tidak hanya sebatas mengingatkan siswa saja sebelum berangkat sekolah sebaiknya terlebih dahulu sarapan, tetapi juga menerangkan bagaimana sarapan pagi sebaiknya dikonsumsi oleh siswa. Guru juga menjelaskan pentingnya sarapan pagi dan manfaatnya bagi tubuh, yang mana dengan sarapan pagi yang sehat bisa membantu mengoptimalkan siswa dalam menerima pelajaran di sekolah. Namun, hal ini belum 
dilakukan karena keterbatasan kemampuan dan pengetahuan guru tentang anemia. Bukubuku kesehatan tentang anemia dan pencegahannya di sekolah untuk menambah pengetahuan juga belum ada, sehingga pengetahuan guru sendiri tentang anemia masih kurang.

Guru memiliki peran penting dalam mengajarkan kebersihan diri kepada anak. Guru berperan sebagai pengajar, mediator, evaluator dan motivator seperti yang di kemukakan oleh (Sardiman, 2011) dan (Melati, 2012). Peran guru terhadap kebersihan anak dapat dilatih melalui kegiatan sehari-hari seperti kebersihan kuku dan membiasakan anak mencuci tangan sesudah melakukan kegiatan dan sebelum makan.

Peran petugas Puskesmas dalam pendidikan kesehtan ini dengan melakukan penyuluhan-penyuluhan kepada siswa pada saat kegiatan UKS di sekolah mengenai makanan yang baik dikonsumsi untuk mencegah anemia, seperti sayur-sayur yang berwarna hijau. Sumber protein yang berasal dari protein hewan seperti daging dan ikan. Petugas Puskesmas menjelaskan apa saja yang menjadi penghambat proses penyerapan besi yang terjadi di tubuh manusia, sehingga siswa bisa berusaha untuk tidak mengkonsumsi makanan/minuman tersebut. Petugas Puskesmas juga dapat memberikan arahan kepada guru tentang anemia sehingga guru di sekolah dapat melanjutkan pemberian pendidikan kesehatan anemia bagi siswa di sekolah.

Dalam pemberian pendidikan kesehatan pencegahan anemia pada siswa di sekolah juga melibatkan peran siswa yang dijadikan kader kesehatan, yang dinamakan dokter kecil. Siswa ditunjuk agar dapat ikut melaksanakan sebagian usaha kesehatan baik itu terhadap dirinya sendiri, keluarganya dan temannya (Handrawan, 2007). Hasil penelitian menunjukkan di sekolah dasar Kabupaten Seluma, dokter kecilnya sudah ada sebanyak 212 siswa. Menurut buku panduan pelaksanaan UKS idealnya jumlah dokter kecil untuk tiap sekolah adalah $10 \%$ dari jumlah siswanya, sehingga peran dokter kecil sebagai kader kesehatan akan seimbang.

Dari jumlah dokter kecil yang ada menunjukkan bahwa dokter kecil masih belum ideal. Jumlah dokter kecil yang tidak sesuai dengan perbandingan jumlah siswa di sekolah menyebakan pelaksanaan kegiatan UKS tidak terlaksana dengan baik sehingga diperlukan pembinaan dan penambahan dokter kecil sekolah. Selain itu dalam pembinaan dokter kecil diberikan materi tentang anemia dan bagaimana cara pencegahan anemia yang dapat dilakukan, sehingga dokter kecil dapat berperan dalam membantu guru dan petugas kesehatan dalam memberikan informasi pada teman-teman sebayanya agar seluruh siswa mendapatkan informasi tentang anemia dan bagaimana cara pencegahan anemia tersebut.

\section{B. Pemanfaatan UKS Melalui Pelayanan Kesehatan}

Pelayanan kesehatan siswa yang dilakukan melalui peran UKS adalah suatu bentuk upaya dalam pecegahan, peningkatan derajat kesehatan, pengobatan serta pemulihan yang dilakukan pada siswa di sekolah yang pelaksanaannya melibatkan guru dan petugas kesehatan (Kemendikbud, 2012). Menurut pedoman pelayanan UKS di sekolah, pelayanan kesehatan pada siswa di sekolah meliputi kegiatan imunisasi, pemberantasan sarang penyakit, upaya alih teknologi kesehatan, pengetahuan kemungkinan adanya penyakit melalui penjaringan dan pemeriksaan kesehatan, pemeriksaan tinggi badan dan pelaksanaan pemeriksaan berat badan, serta melakukan perawatan ke ruang UKS jika ada siswa yang sakit dan dilanjutkan rujukan ke Puskesmas (Direktorat Jenderal Bina Gizi dan Kesehatan Anak, 2011). Peran UKS melalui pemberian layanan kesehatan akan bisa dilaksanakan di sekolah apabila dilakukan bersama dengan Puskesmas terdekat, Dinas Kesehatan Kabupaten/Kota dan dengan petugas kesehatan lain(Sayoga, 2015).

Penimbangan berat badan dan 
pengukuran tinggi badan secara periodik merupakan suatu kegiatan yang bisa memantau status gizi terutama pada anak. Pada anak yang memiliki gangguan status gizi biasanya akan berbanding lurus dengan kurangnya berat dan tinggi badan sesuai ketentuan berdasarkan usia dan jenis kelamin. Kekurangan gizi merupakan faktor yang dapat menyebabkan anemia (Ruel, 2008). Pemeriksaan kesehatan berkala hanya dilakukan satu kali dalam setahun, dikarenakan kurangnya SDM kesehatan yang ada di Puskesmas karena pelayanan kesehatan tidak hanya dilakukan pada siswa sekolah tetapi untuk seluruh lapisan masyarakat, sehingga pelayanan kesehatan pada siswa di sekolah hanya bisa dilakukan satu tahun sekali.

Pada pemeriksaan kesehatan berkala siswa juga belum dilakukan pengambilan darah untuk pemeriksaan kadar hemoglobin. Petugas Puskesmas hanya memeriksa konjungtiva siswa saja untuk menentukan anemia atau tidaknya. Pemeriksaan sampel darah untuk mengukur kadar hemoglobin merupakan standar penentuan yang tepat untuk mengetahui anemia(WHO, 2011).

Berdasarkan telaah dokumen di sekolah yang berhubungan dengan pencatatan hasil kegiatan penjaringan dan pemeriksaan kesahatan berkala di sekolah dasar Kabupaten Seluma, belum terdapat laporan yang dibuat dari guru sekolah untuk kegiatan tersebut, namun di Puskesmas sudah ada laporan tentang penjaringan dan pemeriksaan kesehatan berkala di Puskemas, juga foto-foto pelaksanaan kegiatan tersebut sudah ada untuk melengkapi laporan yang dibuat. Guru sekolah tidak membuat laporan kegiatan tersebut karena petugas Puskesmas juga tidak meneruskan hasil pemeriksaan kesehatan seluruh siswa kepada guru di sekolah. Petugas Puskesmas hanya melaporkan bila ada siswa yang perlu dirujuk ke Puskesmas saja.

\section{Pemanfaatan Sarana dan Prasarana}

Suatu lembaga pendidikan yang menjadi tempat penyaluran segala bentuk pembaharuan merupakan pengertian dari sekolah. Adapun faktor yang tidak dapat diabaikan keberadaan dan peranannya sebagai pendukung keberhasilan kegiatan pembelajaran di sekolah untuk memberikan suatu pembaharuan yaitu sarana prasarananya. Sarana dan prasarana pembelajaran sangatlah memberikan dukungan yang nyata terhadap perubahan sikap yang positif pada siswa. Dimana perubahan itu kelak akan memberikan efek yang berarti bagi perilaku dan sikap mereka (Jannah dan Sontani, 2018).

Berdasarkan buku pedoman pembinaan/pengembangan UKS di sekolah, bahwa sarana prasarana UKS yang ideal di sekolah antara lain adanya ruang UKS yang tidak menyatu dengan ruangan lain, tempat tidur, penimbang badan, pengukur tinggi badan, snellen chart, kotak P3K dan obat-obatan, buku catatan rujukan, rapor kesehatan, gambar berupa poster, tempat cuci tangan/wastafel, dan contoh model organ tubuh (Kemendikbud, 2012). Dalam upaya pemantauan kejadian anemia pada siswa, sarana prasana UKS yang dapat menunjang antara lain ruang UKS, media promosi kesehatan yang berhubungan dengan anemia, buku-buku kesehatan tentang anemia, timbangan, alat ukur tinggi badan dan ketersediaan tempat untuk mencuci tangan.

Pemenuhan kelengkapan sarana dan prasarana UKS memerlukan dukungan dari semua pihak sehingga akan menunjang terciptanya kesehatan masyarakat melalui sekolah. Apabila sarana dan prasarana UKS terutama perihal alat penunjang untuk kegiatan terpenuhi, maka UKS di sekolah dapat terselenggara dengan optimal (Lohrmann, 2008). Berdasarkan hasil pengamatan, sekolah yang sudah mempunyai timbangan dan pengukur tinggi badan belum memanfaatkannya dengan baik karena alat tersebut tampak berdebu ataupun ada juga yang tersimpan di lemari. Semestinya, menurut buku panduan berat dan tinggi badan siswa dapat dilakukan pengukuran minimal enam 
bulan sekali. Sejalan dengan penelitian (Fatmawati et al., 2019), penggunaan peralatan UKS digunakan secara insidental saja dan peralatan yang ada belum terpelihara dengan baik, kalibrasi alat tidak pernah dilakukan dan kebersihannya pun tidak terjaga. Pemanfaatan sarana prasarana harus ditingkatkan dalam pelaksanaan UKS agar mutu layanan yang diberikan dapat meningkat secara terus menerus(Firmansyah et al., 2018).

Promosi kesehatan merupakan salah satu yang dapat meningkatkan mutu dalam pemberian pendidikan kesehatan maupun pelayanan kesehatan disekolah, dilakukan melalui media-media promosi kesehatan misalnya poster, pamflet dan leaflet (Kemendikbud, 2012). Pemberian pendidikan kesehatan tentang anemia dengan menggunakan leaflet membuat siswa lebih tertarik. Akan lebih mudah bagi siswa untuk menerima dan memahami informasi yang disampaikan sehingga penggunaan media kesehatan efektif dalam meningkatkan pengetahuan siswa terhadap anemia dan cara pencegahannya(Haryono et al., 2014).

Hasil penelitian dengan wawancara menunjukkan bahwa guru tidak pernah menggunakan media kesehatan dalam menyampaikan atau mengajarkan kesehatan sebagai upaya pencegahan anemia di sekolah, hal ini disebabkan karena tidak tersedianya media kesehatan di sekolah. Petugas Puskesmas yang memberikan penyuluhan kepada siswa di sekolah juga tidak selalu menyampaikan dengan menggunakan media promosi kesehatan. Pemberian penyuluhan oleh petugas Puskesmas hanya kadang-kadang saja menggunakan media yang dibawa dari Puskesmas.

Hasil observasi di sekolah, hanya satu sekolah yang mempunyai media promosi kesehatan dalam bentuk poster dan leaflet. Tetapi tidak ada sekolah yang memiliki poster atau media promosi kesehatan lainnya tentang pencegahan anemia. Seharusnya melalui pemanfaatan UKS untuk memantau kejadian anemia pada siswa, sekolah memiliki media penyuluhan sehingga dapat digunakan ketika memberikan informasi tentang pendidikan kesehatan kepada siswa.

Keterbatasan media promosi kesehatan yang disediakan Puskesmas seharusnya dapat diatasi oleh sekolah dengan cara yang sederhana. Pamflet dan leaflet dapat diadopsi dari internet dan di cetak dengan menggunakan printer. Selain itu juga sekolah bisa membuat poster kesehatan sendiri dengan mencari gambar-gambar yang bisa dijadikan sebagai poster dengan diberi keterangan tentang tujuan yang ingin disampaikan.

Guru semestinya lebih bisa berinovasi dalam menyampaikan pendidikan kesehatan terhadap siswa di sekolah. Adanya keterbatasan media promosi kesehatan yang digunakan dalam kegiatan penyampaian pendidikan kesehatan ini seharusnya sebisa mungkin diantisipasi, sehingga satu tujuan dari UKS untuk meningkatkan kemampuan hidup sehat dan meningkatkan derajat kesehatan siswa dapat tercapai.

Lima SD pada penelitian ini menunjukkan bahwa ketersediaan sarana dan prasarananya masih sangat kurang. Untuk melengkapi sarana dan prasarana yang dibutuhkan, pihak sekolah bisa membuat perencanaan untuk kelengkapan sarana dan prasarana yang dibutuhkan. Selanjutnya menyampaikan kepada dinas terkait dengan membuat proposal untuk permintaan bantuan pengadaan sarana dan pembuatan prasarana penunjang UKS sehingga dapat dimanfaatkan dengan baik dalam upaya pencegahan anemia pada siswa melalui pelaksanaan UKS di sekolah.

\section{PENUTUP}

Berdasarkan hasil dan pembahasan pada penelitian bisa disimpulkan bahwa pemanfaatan UKS masih belum maksimal pada anak sekolah dasar dalam hal mencegah anemia, pelaksanaan UKS belum memfokuskan pada anemia, peran UKS dalam pendidikan kesehatan belum mengajarkan tentang anemia dan pencegahannya secara 
khusus, peranan UKS dalam pelayanan kesehatan dilakukan dengan pemantauan status gizi yaitu dengan dilakukannya ukur tinggi badan dan timbang berat badan. Keterbatasan sarana dan prasarana UKS membuat pemanfaatannya pun belum maksimal.

Pemanfaatan UKS dalam pencegahan anemia pada anak sekolah dasar di daerah endemik malaria, diharapkan Dinas Pendidikan memberikan pelatihan kepada guru yang ditunjuk untuk bertanggung jawab terhadap kegiatan UKS dan sekolah juga diharapkan dapat meningkatkan kerjasama dengan Puskesmas setempat dalam pemberian pelayanan kesehatan pada siswa, serta melengkapi sarana prasarana yang dibutuhkan.

\section{DAFTAR PUSTAKA}

Badan Penelitian dan Pengembangan Kesehatan. (2013). Riset Kesehatan Dasar. Jakarta.

Devi, N. (2012). Gizi Anak Sekolah. Jakarta: Kompas.

Direktorat Jenderal Bina Gizi dan Kesehatan Anak. (2011). Usaha Kesehatan Sekolah di Tingkat Sekolah Dasar, Sekolah Menengah dan Pondok Pesantren. Jakarta: Direktorat Jenderal Bina Gizi dan Kesehatan Anak.

Fatmawati, F., Sutrisno, S., \& Firdhaushy, H. S. (2019). Penerapan Fungsi Manajemen Pada Program Usaha Kesehatan Sekolah di Sekolah Menengah Pertama. HIGEIA (Journal of Public Health Research and Development), 3(2), 179-189.

Firmansyah, T., Supriyanto, A., \& Timan, A. (2018). Efektivitas Pemanfaatan Sarana dan Prasarana dalam Meningkatkan Mutu Layanan di SMA Laboratorium. Jurnal Manajemen Dan Supervisi Pendidikan, 2(3), 179-184. https://doi.org/10.17977/um025v2i32018 p179

Handrawan, N. (2007). Buku Panduan Untuk Kader Kesehatan Untuk Guru, Masyarakat, Murid. Jakarta :Indonesia.
Haryono, D., Hanim, D., \& Kusnandar, K. (2014). Pengaruh Pendidikan Anemia Gizi Audio Visual dan Leaflet terhadap Tingkat Pengetahuan dan Perilaku Mengkonsumsi Tablet Fe Serta Kadar Hemoglobin pada Remaja Putri. Jurnal Gizi Dan Kesehatan, 1(2).

Jannah, S. N., \& Sontani, U. T. (2018). Sarana dan Prasarana Pembelajaran Sebagai Faktor Determinan Terhadap Motivasi Belajar. Jurnal Pendidikan Manajemen Perkantoran, 3(1), 210 . https://doi.org/10.17509/jpm.v3i1.9457

Juniarti, N., Haroen, H., \& Yani, D. I. (2017). Upaya Penguatan Pelayanan Kesehatan Primer Pada Anak Sekolah Di Pangandaran. Jurnal Pengabdian Kepada Masyarakat (JPKM), 1(4), 232-235.

Kemendikbud. (2012). Pedoman Pembinaan $\mathrm{d}$ a $\mathrm{n}$ P e n g e m b a $\mathrm{g}$ a $\mathrm{n}$ UKS. Http://Www.Mebermutu.Org/Admin/Lamp iran/Pedoman-Pembinaan-Uks.Pdf.

Kemendikbud. (2014). Pedoman Pelaksanaan UKS di Sekolah. Jakarta: Direktorat Jenderal Pendidikan Dasar Kementerian Pendidikan dan Kebudayaan.

Kusmintardjo, \& Gunawan, I. (2017). Manajemen Layanan Khusus (D. E. Kusumaningrum, ed.). Malang: Universitas Negeri Malang.

Lohrmann, D. K. (2008). A Complementary Ecological Model of the Coordinated School Health Program. Public Health Reports, 123 (6), 695-703. https://doi.org/10.1177/003335490812300 $\underline{605}$

Melati, R. (2012). Kiat Sukses Menjadi Guru Paud yang Disukai Anak-Anak. Yogyakarta: Araska.

Ruel, M. T. (2008). Addressing the underlying determinants of undernutrition: Examples of successful integration of nutrition in poverty-reduction and agriculture strategies. In SCN News: Accelerating the reduction of maternal and child nutrition. United Kingdom: Lavenham Press. 
Salama, R. A., \& Labib, M. R. (2016). Prevalence of Anemia Among Informal Primary School Children: A Community Based Study in Rural Upper Egypt. Epidemiology Biostatistics and Public Health, 13(1), 1-7. https://doi.org/10.2427/11567

Sardiman, A. M. (2011). Interaksi dan Motivasi Belajar Mengajar. Jakarta: Raja Grafindo Persada.

Sayoga. (2015). Pendidikan Kesehatan untuk Sekolah Dasar. Bandung: PT Remaja Rosdakarya.

Soliman, A., Kalra, S., \& Sanctis, V. De. (2014).
Anemia and growth. Indian Journal of Endocrinology and Metabolism, 18(7), 1-5. https://doi.org/10.4103/2230-8210.145038 WHO. (2011). Haemoglobin concentrations for the diagnosis of anaemia and assessment of severity. Vitamin and Mineral Nutrition Information System (VMNIS), p. 6. $\mathrm{R}$ e $\mathrm{t} \mathrm{r}$ i e $\mathrm{v}$ e d f r o m https://www.who.int/vmnis/indicators/h aemoglobin.pdf

WHO, \& UNESCO. (2018). Global Standards for Health Promoting Schools (p. 12). p. 12. Geneva. 